\title{
Investigation of Possible Toxic Effects of Personal Care Products on Daphnia magna in the Kucukcekmece Lagoon, Marmara Sea (Turkey) ${ }^{[*]}$
}

\author{
V. Zülal SÖNMEZ ${ }^{1,2, *} \quad$ Nevra ERCAN ${ }^{3} \quad$ Nüket SIVRI $^{1}$ \\ ${ }^{1}$ Department of Environmental Engineering, Istanbul University-Cerrahpasa, TURKEY \\ ${ }^{2}$ Department of Environmental Engineering, Duzce University, TURKEY \\ ${ }^{3}$ Department of Chemical Engineering, Istanbul University-Cerrahpasa, TURKEY
}

How to cite: Sönmez, V.Z., Ercan, N. \& Sivri N. (2020). Investigation of Possible Toxic Effects of Personal Care Products on Daphnia magna in the Kucukcekmece Lagoon, Marmara Sea (Turkey). J. Anatolian Env. and Anim. Sciences, 5(4), 533-540.

Atıf yapmak için: Sönmez, V.Z., Ercan, N. \& Sivri N. (2020). Küçükçekmece Lagünü’nde (Marmara Denizi, Türkiye) Kişisel Bakım Ürünlerinin Daphnia magna Üzerindeki Olası Toksik Etkilerinin Araștırılması. Anadolu Çev. ve Hay. Dergisi, 5(4), 533-540.

: https://orcid.org/0000-0002-7488-2996

iD: https://orcid.org/0000-0001-9927-0315

iD: https://orcid.org/0000-0002-4269-5950
Abstract: Polyethylene glycols (PEGs) used in personal care products (PCPs) are preferred in a wide range of fields thanks to their solubility, viscosity properties, and low toxicity levels which were detected on mammals nearly 60 years ago. This study was aimed to determine the effect of acute toxicity of personal care products and PEGs which are used particularly in personal care and pharmaceutical products on aquatic ecosystems. In this scope, this study was determined the individual acute toxicities of PEGs; the acute toxicity of baby shampoo and body lotion which are among personal care products containing PEGs; and the possible acute toxicity of these products when they reach the surface waters. Daphnia sp. Acute Immobilisation Test was used to determine the toxic effect on aquatic organisms. The acute toxicity class of PEGs was identified as non-toxic (Class 0). While the body lotion was highly toxic (Class 5) at the end of the 48-hour exposure time without being applied to any surface water, it was non-toxic (Class 0) for all stations when applied to surface water. While the baby shampoo was practically non-toxic (Class 1 ) at the end of the 48-hour exposure time without being applied to any surface water, it was slightly toxic (Class 2) for station 1 and station 2 when applied to surface water. When PCPs including these liquid plastics, which are found to have non-toxicity characteristics, it is obvious that different toxic effects can emerge apart from the individual toxicity on surface waters.

Keywords: Acute toxicity, Daphnia magna, Personal Care Products (PCPs), Polyethyleneglycol (PEG), Surface waters.

\section{Corresponding author's:}

Istanbul University-Cerrahpasa, Department of

Environmental Engineering, Istanbul, Turkey

凶: zulal.kiremitci@istanbul.edu.tr

Mobile telephone : +90 (530) 1538999

Fax $\quad:+90(212) 4737180$

\section{Küçükçekmece Lagünü’nde (Marmara Denizi, Türkiye) Kişisel Bakım Ürünlerinin Daphnia magna Üzerindeki Olası Toksik Etkilerinin Araştırılması}

\begin{abstract}
*Sorumlu yazar:
V. Zülal SÖNMEZ

İstanbul Üniversitesi-Cerrahpaşa, Çevre Mühendisliği Bölümü, İstanbul, Türkiye. 凶: zulal.kiremitci@istanbul.edu.tr Mobile telephone : $+90(530) 1538999$ Fax : $+90(212) 4737180$
\end{abstract}

Öz: Kişisel bakım ürünlerinde kullanılan polietilen glikoller (PEG'ler), çözünürlük, viskozite özellikleri ve yaklașık 60 y1l önce memelilerde tespit edilen düșük toksisite seviyeleri sayesinde çok çeșitli alanlarda tercih edilmektedir. Bu çalışmanın amacı, kişisel bakım ürünlerinin ve özellikle kişisel bakım ve eczacılık ürünlerinde kullanılan PEG'lerin sucul ekosistemler üzerindeki akut toksisitesinin etkisini tespit etmektir. Bu kapsamda, bu çalışmada PEG'lerin bireysel akut toksisiteleri; PEG içeren kişisel bakım ürünleri arasında yer alan bebek şampuanı ve vücut losyonunun akut toksisitesi; ve bu ürünlerin yüzey sularına ulaştıklarında olası akut toksisitesi belirlenmiștir. Sucul organizmalar üzerindeki toksik etkiyi belirlemek için, Daphnia sp. Akut Hareketsizlik Testi kullanılmıştır. PEG'lerin akut toksisite sınıfi, toksik olmayan olarak belirlenmiştir (Toksisite Sınıfi-0). Vücut losyonu, 48 saatlik maruziyet süresinin sonunda herhangi bir yüzey suyuna uygulanmadan yüksek derecede toksik (Toksisite sınıf1-5) iken, yüzey suyuna uygulandığında tüm yüzeysel su numuneleri için toksik değil (Toksisite sınıfi-0) olarak belirlenmiştir. Bebek şampuanı, 48 saatlik maruziyet süresinin sonunda herhangi bir yüzey suyuna uygulanmadan pratik olarak toksik olmayan (Toksisite sınıfi-1) iken, yüzey suyuna uygulandığında istasyon 1 ve istasyon 2 için hafif toksiktir (Toksisite sınıfi-2). Toksik olmayan özelliklere sahip olduğu tespit edilen bu sıvı plastikleri içeren PCP'ler, yüzey sularındaki bireysel toksisite dışında farklı toksik etkilerin ortaya çıkabileceği açıktır.

Anahtar kelimeler: Akut toksisite, Daphnia magna, Kișisel Bakım Ürünleri, Polietilen glikol (PEG), Yüzeysel sular. 


\section{INTRODUCTION}

Personal care products (PCPs) comprise a wide range of products such as skin, hair, body care, oral health and dental care, and makeup products. The amount of pharmaceuticals and active ingredients in personal care products, which are used in large quantities around the world, is almost at the same level as the number of agricultural chemicals (Daughton \& Ternes, 1999). The interest in these products has increased in recent years due to the frequency of use and chemical structure of them (Liu \& Wong, 2013), because personal care products, unlike drugs, are not subject to metabolic changes in the human body. Therefore, large quantities of PCPs are mixed directly into the receiving environment without going through any change.

PCPs journey may start from sewage and end in surface water, even in drinking water basins and/or soil(Kim et al., 2009). This results from the disposal of the wastes in treatment plants which cannot be performed by conventional methods (Çetinkaya Karafakı, 2018). These products may be threatening since they are potentially permanent, bio accumulative, biologically active, and continuously discharged into the aquatic environment (Brausch \& Rand, 2011). PCPs are among the most frequently detected compounds among primary pollutants in surface water, even at nanogram levels (Pablos et al., 2015).

Today, another remarkable danger in personal care products are microplastics. Polyethylene microbeads, which are mostly encountered in skin cleaning products, are $10-700 \mu \mathrm{m}$ in diameter and generally below $500 \mu \mathrm{m}$. In such particle sizes, they can easily access the digestive systems of aquatic organisms and may be fatal to them (Wardrop et al., 2016). Microbeads found in personal care products and cosmetics have been recently banned in the USA, Canada, and the European Union. However, it is still widely used in many countries, including Turkey (Hernandez et al., 2017; Ustabaşı \& Baysal, 2019). However, microbeads are not the sole plastic-type found in personal care products.

Different polymeric structures are used as solvent, thickener, plasticizing agent, softener and surfactant in personal care products today. In particular, hydrophilic PEGs having different molecular weights are found in almost all cosmetic product compositions. Depending on the molecular weight, PEGs are used in liquid, waxy solid and solid forms in cosmetic, pharmaceutical and food industries. Food and Drug Administration (FDA), based on the Inactive Ingredient Database (FDA, 2019) declared that the maximum amount used of PEG decreased in line with increasing molecular weight PEG 400, 4000, 6000 and 8000 are $960.48,449.6,450$ and $100 \mathrm{mg}$ per dosage form, respectively.

There are studies conducted on sources, fate, and effects of microplastics in aquatic and terrestrial environments; their uptake by organisms and possible effects on them (Cheung \& Fok, 2016; Duis \& Coors, 2016; Kalčíková et al., 2017; Lei et al., 2017). In the literature review, therefore, it is difficult to come across a study conducted on the fate and effects of water-soluble liquid plastics contained in these products. Previous studies investigated the intended use of various PEG compounds and concluded that their use in cosmetics is relatively safe for public health (CIR Expert Panel, 2004; Fruijtier-Pölloth, 2005; Jang et al., 2015; Lanigan et al., 2001). The number and variety of PEGs studied remained limited due to the wide range of PEGs. Considering the importance of PCPs, the addition of new products, the advancement of technology and public health as well as environmental health, it is believed that the current studies fall short to reflect the future picture.

Chronic and acute tests conducted with Daphnia magna are among the most common studies in the field of aquatic toxicology (Martins et al., 2007; Sönmez et al., 2016). D. magna has been an essential organism for ecotoxicology due to its ease of reproduction in the laboratory and its place in the food chain (Imhoff et al., 2017). It also makes it possible to use these organisms to determine the toxicity of liquid plastics because they are fed by filtering water.

This study was aimed to determine the effect of acute toxicity of personal care products and PEGs which are used particularly in personal care and pharmaceutical products on aquatic ecosystems. In this scope, this study was determined the individual acute toxicities of PEGs; the acute toxicity of baby shampoo and body lotion which are among personal care products containing PEGs; and the possible acute toxicity of these products when they reach the surface waters. Samples of surface waters with seawater, freshwater and brackish water composition were taken to determine the toxic effect of PCPs in surface waters.

\section{MATERIAL AND METHOD}

In this study, PEG was selected as polymer material and subjected to acute toxicity tests at different concentrations. As PEG products are present alone, two different PCP products containing PEG were selected and their acute toxicity was studied. Finally, a scenario was created for the discharge of selected PCPs to the surface waters (seawater, freshwater and brackish water) with 3 different compositions and the acute toxicity test was applied in the prepared sets.

Selection of PEGs: Polyethylene glycols 200, 300, 400 and 600 are fluid and 1000, 2000, 4000, 6000 and 10.000 are solid. The number demonstrates the mean molecular weight of polyethylene glycols in a given product. Table 1 
presents the PEGs selected within the scope of the present study and their use in PCPs. In the experimental studies, PEGs of Sigma-Aldrich brand were used.

Table 1. PEGs selected within the scope of the present study and their use in PCPs (Jang et al., 2015).

\begin{tabular}{ll}
\hline Polymer & Description as cosmeticingredients \\
\hline PEG 600 & $\begin{array}{l}\text { Humectant, Shower and bath products, creams and lotions, } \\
\text { shampoos, shaving products and liquid soaps. } \\
\text { Perfume fixative, softener, non-greasylubricant. Moisture } \\
\text { stabilizing effect in creams. Leaves a pleasant feel on the skin. } \\
\text { PEG 1500 }\end{array}$ \\
Inlotions, acts as a cleansing agent. \\
PEG 2000 $6000 \quad \begin{array}{l}\text { Nonionic, moisturizing, lubricating } \\
\text { Non-ionic, binder, lubricant, suspending agent }\end{array}$ \\
PEG 10000 & $\begin{array}{l}\text { Slip and mold-release agent, water soluble carrier substance, } \\
\text { feel on the skin. }\end{array}$ \\
\hline
\end{tabular}

Selection of PCPs: Two different products, baby shampoo, and body lotion were selected as personal care products having the common feature of containing PEG. In addition to having PEG in common, both products have the potential to be eco-friendly/greener than other products.

The first product, baby shampoo is widely used in Turkey, its chemical content is formed for relatively sensitive skins due to its usage area. The product is stated to be in line with the Cosmetic Act no. 5324 and Cosmetic Regulation in force in Turkey which were modelled and prepared in accordance with the Regulation (EC)No 1223/2009 of the European Parliament and of the Council on Cosmetic Products. It contains mix of PEG esters (as polyethyleneglycol oleate and polyethyleneglycol stearate) along with different chemicals.

The other product, body lotion is produced by an environmentally sensitive company. It is sold at higher prices since it is known to be more sensitive to its equivalents in the Turkish market. It contains the compound of PEG esters (polyethyleneglycol stearate) along with different chemicals.

Selection of Surface Waters: It is observed that water quality has deteriorated as pollution levels increased over time in the Kucukcekmece Lagoon where seawater, freshwater, and brackish water compositions coexists in Istanbul province (Sivri et al., 2012). Both the connection of the lake to the Sea of Marmara and the pollution carried by rivers to the lake further increased the pressure on it. The sample of the surface water was collected to identify the toxicity of personal care products, the toxicity of which was determined in surface water. Samples were taken from 3 different stations from surface water with different composition on the southwest coast of Istanbul.

Special attention was paid to the dispersibility of PCPs at different salinity rates while selecting the stations. Therefore, the Avcrlar Coast, which is connected with the lagoon, with seawater composition (Station 1), the channel of Kucukcekmece Lagoon, which has a channel for transitional waters between the lake and sea, with brackish water composition (Station 2), and Kucukcekmece Lagoon with a composition close to freshwater (Station 3) were selected. The information obtained regarding these stations is presented in Table 2. The general view of the stations is presented in Figure 1.

Table 2. Sampling Stations and compositions of surfacewaters'.

\begin{tabular}{llll}
\hline Stations & Name of Stations & Composition of water (\%) & Coordinates \\
\hline Station 1 & Avclar Coast & Seawater (22\%) & $40^{\circ} 58^{\prime} 47,11^{\prime \prime} \mathrm{N} 28^{\circ} 46^{\prime} 8,07^{\prime \prime} \mathrm{E}$ \\
Station 2 & Kucukcekmece Channel & Brackish water (11\%) & $40^{\circ} 58^{\prime} 51,13^{\prime \prime} \mathrm{N} 28^{\circ} 46^{\prime} 23,51^{\prime \prime} \mathrm{E}$ \\
Station 3 & Kucukcekmece Lake & Freshwater (6\%) & $40^{\circ} 59,4^{\prime} 48^{\prime \prime} \mathrm{N} 28^{\circ} 45^{\prime} 45,80^{\prime \prime} \mathrm{E}$ \\
\hline
\end{tabular}

In accordance with Water Pollution Control Instruction Methods of Sampling and Analysis, surface water samples taken from each station were brought to Microbiology Research Laboratory (CEMIK) in Department of Environmental Engineering at Istanbul UniversityCerrahpasa.

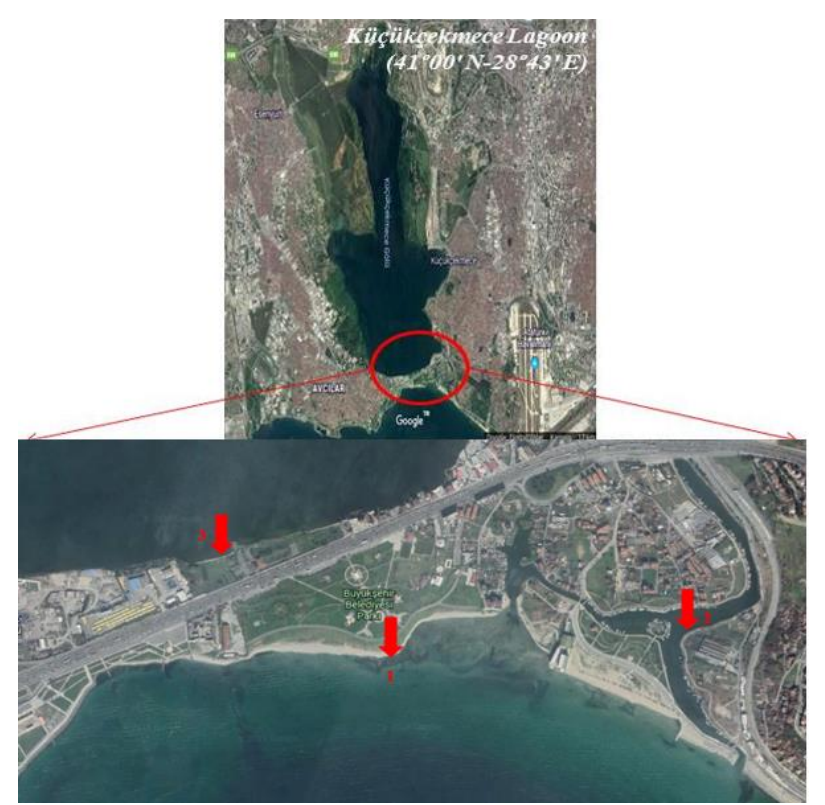

Figure 1. General view of the study area (adapted from Google Earth).

The test was based on the OECD guideline Daphnia magna Acute Immobilisation Test (OECD, 2004). Daphnids not older than 24 hours were exposed to the sample concentration. The vessels were completely filled with appropriate volumes of dilution water and samples. First of all, individual acute toxicity of PEGs was studied (Figure 2). Preliminary tests were performed to determine the concentration range. Afterwards, 100, 80, 40, 20, 10, 5, 1 and $0.1 \mathrm{~g} \mathrm{~L}^{-1}$ concentrations at which immobility/immortality was observed for each PEG.

In the second step, preliminary tests were performed to detect the concentrations of baby shampoo and body lotion (Figure 2). According to the data obtained, the concentrations of body lotion to be studied were determined as $20 \mathrm{~g} \mathrm{~L}^{-1}, 10 \mathrm{~g} \mathrm{~L}^{-1}, 5 \mathrm{~g} \mathrm{~L}^{-1}, 1 \mathrm{~g} \mathrm{~L}^{-1}, 0.5 \mathrm{~g} \mathrm{~L}^{-1}, 0.25 \mathrm{~g} \mathrm{~L}^{-1}$, $0.10 \mathrm{~g} \mathrm{~L}^{-1}, 0.05 \mathrm{~g} \mathrm{~L}^{-1}$, and $0.01 \mathrm{~g} \mathrm{~L}^{-1}$, respectively. For baby shampoo, the toxicity test was performed at concentrations; 
$1 \mathrm{~g} \mathrm{~L}^{-1}, 0.8 \mathrm{~g} \mathrm{~L}^{-1}, 0.6 \mathrm{~g} \mathrm{~L}^{-1}, 0.5 \mathrm{~g} \mathrm{~L}^{-1}, 0.4 \mathrm{~g} \mathrm{~L}^{-1}, 0.25 \mathrm{~g} \mathrm{~L}^{-1}, 0.2$ $\mathrm{g} \mathrm{L}^{-1}$, and $0.05 \mathrm{~g} \mathrm{~L}^{-1}$. In the final step, the body lotion and baby shampoo were applied to surface water samples (Figure 2).

Then, Daphnids were placed into test beakers. Minimum $2 \mathrm{~mL}$ of test solution was needed for each test organism; hence $50 \mathrm{~mL}$ test media was studied for 10 daphnids. The organisms were unfed and did not go through the aeration during the test. The temperature, $\mathrm{pH}$ and DO values were checked. The controls were kept under the same conditions. Studies were performed in parallel for each set. In addition, low-speed (60 rpm) rinsing movement was applied to ensure adaptation to natural conditions.

Any immobility and abnormal behaviour were recorded after 24 and 48 hours. Each beaker was checked for immobilized daphnids at the 24th and 48th hours. For each period ( 24 and 48 hours) during which the observations were recorded, the test result was expressed as $\mathrm{EC}_{50}$ with the Probit Analysis method as proposed by EPA to express the dose-response relationship (EPA, 1991).

During acute exposures, daphnids observed to be immobilized were taken from the test environment. At the end of the experiment, immobilized/dead daphnids in each beaker were analysed in KRUSS brand-MBL 2000 binocular microscope environment; physical integrity of organisms was analysed and photographed.

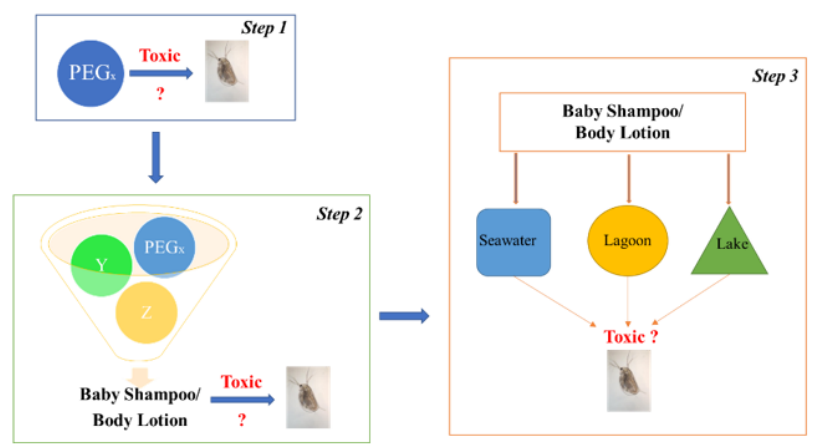

Figure 2. Experimental set.

Classification of Acute Toxicity: It is possible for products containing PEGs, and PEGs to mix in surface waters unless they are satisfactorily or appropriately dissolved at wastewater purification plants. Therefore, this study grounds on the toxicity classification which is based on toxicity in wastewaters (Table 3).

Table 3. Classification of toxicity (adapted from GESEAMP (2017))

\begin{tabular}{ccl}
\hline Classification & EC $_{\mathbf{5 0}}\left(\mathbf{m g ~ L}^{\mathbf{- 1}}\right)$ & AcuteToxicity \\
\hline 0 & $>1000$ & Non-Toxic \\
1 & $>100-\leq 1000$ & PracticallyNon-toxic \\
2 & $>10-\leq 100$ & SlightlyToxic \\
3 & $>1-\leq 10$ & ModeratelyToxic \\
4 & $>0.1-\leq 1$ & High Toxic \\
5 & $>0.01-\leq 0.1$ & Very High Toxic \\
6 & $\leq 0.01$ & ExtremelyToxic \\
\hline
\end{tabular}

\section{RESULTS AND DISCUSSION}

No mortality/immobility was observed in the control group after the 24- and 48- hour exposure time for all sets. Findings of each set are presented below under separate titled.

Acute Toxicity Classification of PEGs: Figure 3 presents the immobilization rate $(\%)$ at the end of 24- and 48-hours exposure of the acute toxicity test performed with D. magna for PEG 600, 1500, 2000, 6000 and 10.000 . Generally, mortality rates increased with increasing exposure time (expect PEG 600). Considering the 24-hour exposure, in general, mortality rates reduced as the number of PEG molecules increased (expect PEG 6000). No immobile/dead daphnids were counted at either concentration of $1 \mathrm{~g} \mathrm{~L}^{-1}$ or $0.1 \mathrm{~g} \mathrm{~L}^{-1}$ studied for both exposure periods. For PEG 6000 and PEG 10000, the mortality rate was found to be $50 \%$ or more after the 48 -hours of exposure.
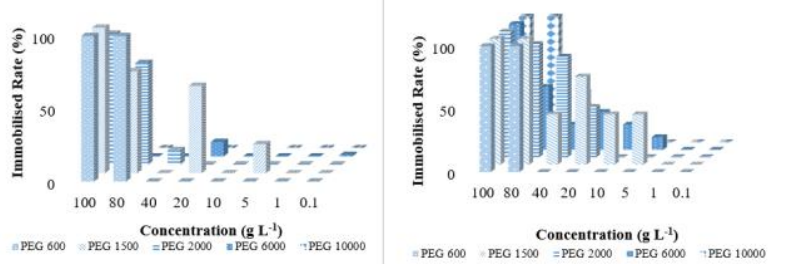

Figure 3. Concentration-affiliated immobilized rate at the end of exposure ( 24 and 48 hours from left to).

Table 4 presents the acute toxicity value of the PEGs studies as $\left(\mathrm{EC}_{50}\right) \mathrm{g} \mathrm{L}^{-1}$ and the related acute toxicity class. Accordingly, PEG 600, 1500, 2000, 6000 and 10.000 did not have any acute toxicity effect on D. magna and were identified as non-toxic. Studies on the toxicological and physiological effects of PEGs have been published in a few journals several years ago. Acute toxicity of different PEGs ranging from PEG 200 to PEG 10.000 on Guinea pig and rabbit, was studied especially between 1938 and 1949. In a study conducted by Symth et al., (1950), the findings obtained were in parallel with the previous studies showing that acute oral toxicity and dermal toxicity were very low. In a review by Fruijtier-Pölloth, (2005), it was also found that most of the PEGs and their derivatives studied so far cause very low toxicity after single or repeated exposure to mammals.

At the end of the 24-hour exposure time, a linear relationship was found between $\mathrm{EC}_{50}\left(\mathrm{~g} \mathrm{~L}^{-1}\right)$ and $\mathrm{PEG}$ molecular weight, just as in mortality $(\%)$. However, $\mathrm{EC}_{50}$ values at and above $1000 \mathrm{mg} \mathrm{L}^{-1}$ are classified as non-toxic. Therefore, the relationship has no effect on the toxicity class. In the study conducted by Symth et al. (1950), clear tendency towards a slight decrease in acute toxicity was interpreted with large increases in molecular weight. The statement of reduced toxicity as molecular weight increases is also 
reported inreview of Fruijtier-Pölloth (2005) on polyethylene glycols (PEGs) and derivatives used in cosmetic products.

Table 4. Acute toxicity rates and classes of PEGs.

\begin{tabular}{|c|c|c|c|c|}
\hline Exposure Time & & $4 \mathrm{~h}$ & & $8 \mathrm{~h}$ \\
\hline Sample & $\begin{array}{l}\text { EC50 } \\
\left(\mathrm{g} \mathrm{L}^{-1}\right)\end{array}$ & $\begin{array}{c}\text { Classification of } \\
\text { acutetoxicity }\end{array}$ & $\begin{array}{l}\text { EC50 } \\
\left(\mathrm{g} \mathrm{L}^{-1}\right)\end{array}$ & $\begin{array}{c}\text { Classification of } \\
\text { acutetoxicity }\end{array}$ \\
\hline PEG 600 & $>10000$ & 0 & $>10000$ & 0 \\
\hline PEG 1500 & 20.917 & 0 & 22.861 & 0 \\
\hline PEG 2000 & 65.216 & 0 & 25.280 & 0 \\
\hline PEG 6000 & $>100000$ & 0 & $>100000$ & 0 \\
\hline PEG 10000 & $>100000$ & 0 & $>100000$ & 0 \\
\hline PEG 600 & $>10000$ & 0 & $>10000$ & 0 \\
\hline
\end{tabular}

Apart from calculating $\mathrm{EC}_{50}$ values affiliated to mortality rates, dead/immobilized daphnids were examined with a microscope to see the effect of exposure. A microscopic image of D. magna in control is presented in Figure 4 for a more solid comparison. Negative effects of the exposure were detected on daphnids in PEG 600, unlike other PEGs, at the $24^{\text {th }}$ hour (Figure $5-\mathrm{a}, \mathrm{b}$ ). At the $48^{\text {th }}$ hour of exposure, the effects of PEG 2000 (Figure 6) and PEG 6000 (Figure 7) were detected on Daphnids in addition to PEG 600 (Figure 5-c, d) at the highest concentrations studied (100 and $80 \mathrm{~g} \mathrm{~L}^{-1}$ ). This effect, particularly emerging at high concentrations, is due to the fact that daphnids' digestion systems decrease in volumeIn the literature, no related finding has been found, so this behaviour is important.

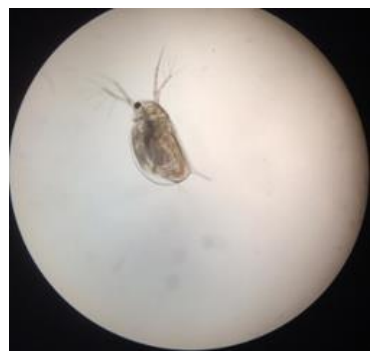

Figure 4. Microscope image of living Daphnia magna in control sample (Magnification power $4 \times 10$ ).
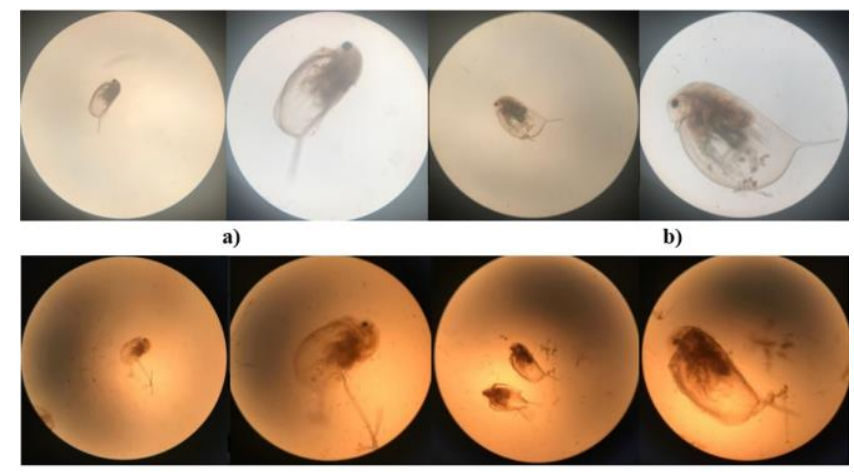

c)

d)

Figure 5. The effects of PEG 600 on daphnids after the 24-hour exposure a) $100 \mathrm{~g} \mathrm{~L}^{-1}$ (Magnification power, respectively $=4 \mathrm{x} 10$ and 10x10) b) $80 \mathrm{~g} \mathrm{~L}^{-1}$ (Magnification power, respectively $=4 \times 10$ and 10x10), The effects of PEG 600 on daphnids after the 48-hour exposure c) $100 \mathrm{~g} \mathrm{~L}^{-1}$ (Magnification power, respectively $=4 \times 10$ and $10 \times 10$ ) d) $80 \mathrm{~g} \mathrm{~L}^{-1}$ (Magnification power, respectively $=4 \times 10$ and $10 \times 10)$.
This finding is important to indicate that the effect on the aquatic organisms may differ by the chemical structure of the polymer type studied. However, this negative effect is thought to be due to the difference in density of working PEGs, which are distinctive features of the polymer, rather than chemical bonds. It is believed more polymers are taken by the daphnids since they are fed by draining water and the density of PEG 600 is relatively lower than PEG 2000 and PEG 6000 (PEG 600 (1.126 $\mathrm{g} \mathrm{cm}^{-3}$ ), PEG 2000 $\left(1.21 \mathrm{~g} \mathrm{~cm}^{-3}\right)$, and PEG $6000\left(1.2 \mathrm{~g} \mathrm{~cm}^{-3}\right)$ respectively).

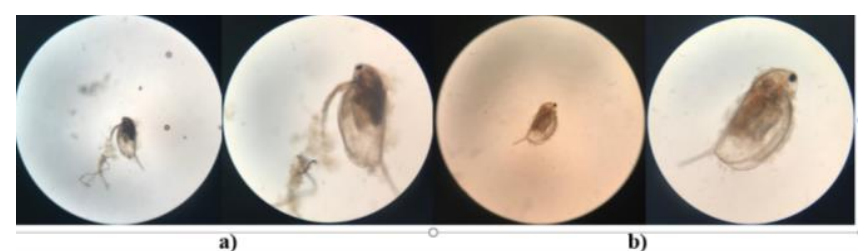

Figure 6. The effects of PEG 2000 on daphnids after the 48-hour exposure a) $100 \mathrm{~g} \mathrm{~L}^{-1}$ (Magnification power, respectively $=4 \times 10$ and $10 \times 10$ ) b) $80 \mathrm{~g} \mathrm{~L}^{-1}$ (Magnification power, respectively $=4 \times 10$ and $10 \times 10)$

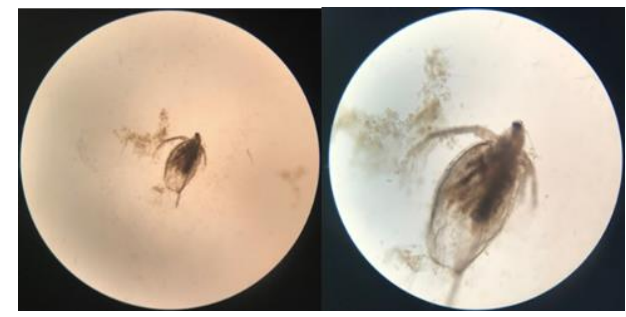

Figure 7. The effects of PEG 6000 on daphnids after the 48-hour exposure-100 $\mathrm{g} \mathrm{L}^{-1}$ (Magnification power, respectively $=4 \times 10$ and $10 \times 10)$.

Acute Toxicity Classification of PCPs: For body lotion, the $\mathrm{EC}_{50}$ value was found to be $1547 \mathrm{mg} \mathrm{L}^{-1}$ at the end of the 24-hour test period while it was found $0.039 \mathrm{mg} \mathrm{L}^{-1}$ at the end of the 48-hour test period. In terms of acute toxicity classification, the class of body lotion changed from 0 (nontoxic) to 5 (very high toxic). The body lotion toxicity value $\left(0.039 \mathrm{mg} \mathrm{L}^{-1}\right)$ obtained at the end of 48 hours was found to be higher than the 24-hour test period, and there was a major alteration among the acute toxicity class. Although the concentration of this active substance remained constant, it led to an increase in toxicity with the increase in contact time with the organism. Famous toxicologists like Peter Wells stated that toxicity depends on both concentration and exposure time and presents on a comprehensive basis (Wells, 1984; Lessard \& DeMarco, 2000). For a healthy interpretation of the results, 24 and 48 hour $\mathrm{EC}_{50}$ values, $\mathrm{EC}_{50}\left(\mathrm{mg} \mathrm{L}^{-1}\right)$ and acute toxicity classification are presented in Table 5 for body lotion and baby shampoo. For baby shampoo, the $\mathrm{EC}_{50}$ value was found to be $316.35 \mathrm{mg} \mathrm{L}^{-1}$ at the end of the 24-hour test period while it was $177.47 \mathrm{mg} \mathrm{L}^{-}$ ${ }^{1}$ at the end of the 48 -hour test period. There was no change in acute toxicity class in the 24- and 48-hour exposures.

Studies in the literature are mainly carried out on the individual toxicity of the chemicals contained in personal 
care products (Daughton \& Ternes 1999). Safety Data Sheets (SDS), prepared by each brand, show information about the ecotoxicity of the ingredients. In the SDS study, it was found that the mean result of acute toxicity test of the chemical having the highest percentage in hand\&body lotion products of different brands performed with D. magna, varied between $1.955 \mathrm{mg} \mathrm{L}^{-1}(48 \mathrm{~h})$ and $>500 \mathrm{mg} \mathrm{L}^{-1}(24 \mathrm{~h})$. Results of the acute toxicity test performed D. magna for chemicals contained in the baby shampoo of a certain brand varied between $0.12 \mathrm{mg} \mathrm{L}^{-1}$ and $2564 \mathrm{mg} \mathrm{L}^{-1}$. The literature review shows that the toxicities of the chemicals usually contained in each PCP are studied individually and not evaluated on a product basis (Brausch \& Rand, 2011).

The study supports the difference in toxicity found at 24 and 48 hour exposure time. Acute toxicity test results of a brand with $D$. magna for chemicals in baby shampoo contents vary between $0.12 \mathrm{mg} \mathrm{L}^{-1}$ and $2564 \mathrm{mg} \mathrm{L}^{-1}$. When the literature is evaluated, it is seen that the toxicities of the chemicals usually included in each PCP are studied individually and not evaluated on a product basis.

Table 5. The mean of acute toxicity test result of body lotion and baby shampoo.

\begin{tabular}{lcccc}
\hline Exposure Time & \multicolumn{2}{c}{$\mathbf{2 4} \mathbf{~ h}$} & $\mathbf{4 8 ~ \mathbf { ~ }}$ \\
\hline Sample & $\begin{array}{c}\mathbf{E C} 50 \\
\left(\mathbf{g ~ L}^{-1}\right)\end{array}$ & $\begin{array}{c}\text { Classification of } \\
\text { acutetoxicity }\end{array}$ & $\begin{array}{c}\mathbf{E C}_{50} \\
\left(\mathbf{g ~ L}^{-1}\right)\end{array}$ & $\begin{array}{c}\text { Classification of } \\
\text { acutetoxicity }\end{array}$ \\
\hline Body Lotion & $<1547$ & 0 & 0.039 & 5 \\
Baby Shampoo & 316.35 & 1 & 177.47 & 1 \\
\hline
\end{tabular}

Acute Toxicity Classification of PCPs Interaction with Surface Waters: In this part of the study, the toxicity of the surface water samples was determined as the first step. It was studied at $50 \%, 25 \%, 12.5 \%$ and $6.25 \%$ for each station, and high mortality rates were found in the toxicity test.

The $\mathrm{EC}_{50}$ value after the 48 -hour test period was found to be $46.37 \mathrm{mg} \mathrm{L}^{-1}$ for station 1 and $\mathrm{EC}_{50}>100 \mathrm{mg} \mathrm{L}^{-1}$ for station 2 and 3. It was determined that surface water samples with fresh and brackish water composition taken from the stations 2 and 3 were practically non-toxic (Class 1 ), and the seawater sample taken from station 1 was slightly toxic (Class 2) (Table 6). It was determined that the station 1 was different from the other stations since the chemical structures may also lead to salinity as involved in seawater. The toxicity of the samples was considered, a $3.125 \%$ dilution rate at which no mortality was observed was taken as a basis in the study. With this study, an optimistic scenario was created for the contamination of personal care products in the sampling area. The potential toxic effects of the presence of personal care products in non-toxic concentrations in aquatic areas have been tried to be determined with different scenarios. Thus, the body lotion and baby shampoo were applied to surface water samples diluted at the specified rate.

Table 6. Acute toxicity classification of surface waters and PCPs interaction with surface waters.

\begin{tabular}{lcccccc}
\hline Exposure Time & $\begin{array}{c}\mathbf{E C}_{\mathbf{5 0}} \\
\left(\mathbf{g ~ L}^{-1}\right)\end{array}$ & $\begin{array}{c}\text { Classification of } \\
\text { acutetoxicity }\end{array}$ & $\begin{array}{c}\mathbf{E C}_{\mathbf{5 0}} \\
\left(\mathbf{g ~ L ~ L}^{-1}\right)\end{array}$ & $\begin{array}{c}\text { Classification of } \\
\text { acutetoxicity }\end{array}$ & $\begin{array}{c}\mathbf{E C}_{\text {50 }} \\
\left(\mathbf{g ~ L}^{-1}\right)\end{array}$ & $\begin{array}{c}\text { Classification of } \\
\text { acutetoxicity }\end{array}$ \\
\hline Sample & & Surface waters & & Body Lotion & 0 & Baby shampoo \\
\hline Station 1 & 46.37 & 2 & 4927 & 0 & 62.67 & 2 \\
Station 2 & 567.8 & 1 & 1100 & 0 & 85.18 & 2 \\
Station 3 & 211.54 & 1 & 4927 & 0 & 118.62 & 1 \\
\hline
\end{tabular}

Depending on the concentrations studied in the determined toxicity of the body lotion, $20000 \mathrm{mg} \mathrm{L}^{-1}, 1000$ $\mathrm{mg} \mathrm{L}{ }^{-1}, 100 \mathrm{mg} \mathrm{L}^{-1}, 10 \mathrm{mg} \mathrm{L}^{-1}$ concentrations were selected. Depending on the concentrations studied in the determined toxicity of the baby shampoo, $1000 \mathrm{mg} \mathrm{L}^{-1}, 500 \mathrm{mg} \mathrm{L}^{-1}$, $100 \mathrm{mg} \mathrm{L}^{-1}, 50 \mathrm{mg} \mathrm{L}^{-1}$ concentrations were selected to study. 48-hour toxicity test results of the application of the body lotion and baby shampoo to surface water are presented as $\mathrm{EC}_{50}$ and classification of acute toxicity in Table 4 . While the body lotion was highly toxic (Class 5) at the end of the 48-hour exposure time without being applied any surface water, it was non-toxic (Class 0) for all stations when applied to surface water. When PEGcontaining PCPs are applied to surface waters, it is possible to claim that even PEG-containing non-toxic products can cause toxicity in the aquatic ecosystem because surface waters (especially seawater) are composed of different chemical structures. While the baby shampoo was practically non-toxic (Class 1) at the end of the 48-hour exposure time without the being applied to any surface water, it was slightly toxic (Class 2) for station 1 and station 2 when applied to surface water. In addition, baby shampoo application to surface waters changed the toxicity class of the station 2 (from Class 1 to Class 2). The baby shampoo was practically non-toxic only for station 3 .

\section{CONCLUSION}

To our knowledge, this is the first study to examine PEGs, which are known to be non-toxic, in natural waters. This study proves the non-toxic feature of only PEGs $(600,1500,2000,6000$ and 10000) on were on $D$. magna. In summary, PEGs are non-toxic, but PEGs are not used alone in PCPs. Different chemical structures (mists and sulfate structures) contained in PEG-containing products may cause toxicity. In particular, structures that are toxic, carcinogenic to the environment and public health should be strictly excluded from PCPs formulations of these products. To conclude, even specific assessments on each chemical mixture do not mean that those personal 
care products are completely safe for the environment. When the personal care products including these liquid plastics, which are found to have non-toxicity characteristics, it is obvious that different toxic effects can emerge apart from the individual toxicity.

\section{ACKNOWLEDGEMENTS}

The authors specially thank Seda AKBULUT, Merve VARBIL, Görkem SANDIKCI, Nilay ELMACIOĞLU and Vedat ELLIALTI for their excellent technical assistance and cooperation. This study was supported by the Scientific Research Project Coordination Unit of Istanbul University-Cerrahpaşa, Project Number: FBA-2018-32551.

\section{REFERENCES}

Brausch, J.M. \& Rand, G.M. (2011). A review of personal care products in the aquatic environment: Environmental concentrations and toxicity. Chemosphere, 82(11), 1518-1532. DOI: 10.1016/j.chemosphere.2010.11.018

Cheung, P.K. \& Fok, L. (2016). Evidence of microbeads from personal care product contaminating the sea. Marine Pollution Bulletin, 109(1), 582-585. DOI: 10.1016/j.marpolbul.2016.05.046

CIR Expert Panel. (2004). Final report of the amended safety assessment of PEG-5, -10, -16, -25, -30, and -40 soy sterol. International Journal of Toxicology, 23, 23-47.

Çetinkaya Karafakı, F. (2018). İlaç, kozmetik ve kişisel bakim ürünleri atıklarının çevre üzerine etkileri ve $\mathrm{AB}$ Ülkelerinin ve Türkiye'nin bakış açısı. Journal of Disaster and Risk, 1(1), 63-71. (in Turkish).

Daughton, C.G. \& Ternes, T.A. (1999). Pharmaceutical sand personal care products in the environment: Agents of subtlechange? Environmental Health Perspectives, 107(6), 907-938. DOI: 10.1289/ehp.99107s6907

Duis, K. \& Coors, A. (2016). Microplastics in th eaquatic and terrestrial environment: Sources (with a specific focus on personal care products), fate and effects. Environmental Sciences Europe, 28(2), 125. DOI: $10.1186 / \mathrm{s} 12302-015-0069-\mathrm{y}$

EPA. (1991). Short Term Methods for Estimating The Chronic Toxicity of Effluents and Receiving Waters to Fresh Organisms; U.S Environmental Protection Agency, U.S. Army Corps of Engineers, Washington.

FDA (Food and Drug Administration). (2019). https://www.fda.gov/. (20 August 2019).

Fruijtier-Pölloth, C. (2005). Safety assessment on polyethylene glycols (PEGs) and their derivatives as used in cosmetic products. Toxicology, 214, 138. DOI: $10.1016 /$ j.tox.2005.06.001

GESEAMP.

(2002)

$\mathrm{MO} / \mathrm{FAO} / \mathrm{UNESCO} \pm \mathrm{IOC} / \mathrm{WMO} / \mathrm{WHO} / \mathrm{IAEA} / \mathrm{U}$

N/UNEP Joint Group of Experts on the Scientific
Aspects of Marine Environmental Protection. https://www.jodc.go.jp/info/ioc_doc/GESAMP/ GESAMP64.pdf. (6 June 2019).

Hernandez, L.M., Yousefi, N. \& Tufenkji, N. (2017). Are the renanoplastics in your personal care products? Environmental Science \& Technology Letters, 4(7), 280-285. DOI: 10.1021/acs.estlett.7b00187

Imhof, H.K., Rusek, J., Thiel, M., Wolinska, J. \& Laforsch, C. (2017). Do microplastic particles affect Daphnia magna at themorphological, life history and molecular level? PloSone, 12(11), e0187590. DOI: 10.1371/journal.pone.0187590

Jang, H.J., Shin, C.Y. \& Kim, K.B. (2015). Safety evaluation of polyethyleneglycol (PEG) compounds for cosmeticuse. Toxicological Research, 31(2), 105 .

Kalčíková, G., Alič, B., Skalar, T., Bundschuh, M. \& Gotvajn, A.Ž. (2017). Wastewater treatment plant effluents as source of cosmetic polyethylene microbeads to freshwater. Chemosphere, 188, 2531. DOI: 10.1016/j.chemosphere.2017.08.131

Kim, J.W., Ishibashi, H., Yamauchi, R., Ichikawa, N., Takao, Y., Hirano, M., Koga, M. \& Arizono, K. (2009). Acute toxicity of pharmaceutical and personal care products on freshwater crustacean (Thamnophilus platyuru) and fish (Oryzias latipes). The Journal of Toxicological Sciences, 34(2), 227-232. DOI: 10.2131/jts.34.227

Lanigan, R.S. \& Yamarik, T.A. (2001). Cosmetic Ingredient Review Expert Panel, Final report on the safety assessment of PEG-6, -8, and -20 sorbitanbeeswax. International Journal of Toxicology, 20, 27-38.

Lei, K., Qiao, F., Liu, Q., Wei, Z., Qi, H., Cui, S., Yue, X., Deng, Y. \& An, L. (2017). Microplastics releasing from personal care and cosmetic products in China. Marine Pollution Bulletin, 123(1-2), 122-126.

10.1016/j.marpolbul.2017.09.016

Lessard, R.R. \& DeMarco, G. (2000). The significance of oil spill dispersants. Spill Science \& Technology Bulletin, $\mathbf{6}(1), \quad 59-68 . \quad$ DOI: 10.1016/S1353-2561(99)00061-4

Liu, J.L. \& Wong, M.H. (2013). Pharmaceuticals and personal care products (PPCPs): A review on environmental contamination in China. Environment International, 59, 208-224. DOI: 10.1016/j.envint.2013.06.012

Martins, J., Teles, L.O. \& Vasconcelos, V. (2007). Assays with Daphnia magna and Danio rerio as alert systems in aquatic toxicology. Environment International, 33(3), 414-425. DOI: 10.1016/j.envint.2006.12.006

OECD. (2004). Guideline 202: Daphnia sp. Acute Immobilisation Test, Adopted 14 April 2004. OECD Guideline for the Testing of Chemicals. Organisation for Economic Cooperation and Development, France.

Pablos, M.V., García-Hortigüela, P. \& Fernández, C. (2015). Acute and chronic toxicity of emerging 
contaminants, alone or in combination, in Chlorella vulgaris and Daphnia magna. Environmental Science and Pollution Research, 22(7), 5417-5424.

Sivri, N., Seker, D.Z., Balkis, N. \& Zan, A. (2012). Analysis of chlorophyll-a distribution on the south-western coast of Istanbul during 2008-2010 using GIS. Fresenius Environmental Bulletin (FEB),21(11), 3233-3242. DOI: 10.1371/journal.pone.0187590

Smyth, H.F., Carpenter, C.P. \& Weil, C.S. (1950). The toxicology of the polyethylene glycols. Journal of the American Pharmaceutical Association (Scientific ed.), 39(6), 349-354.

Sönmez, V.Z., Sivri, N. \& Dökmeci, A.H. (2016). Determination of The Toxicity of Different Discharge Waters using Acute Toxicity Tests Approved for National Pollutant Discharge Permit in Turkey. Biosciences, Biotechnology Research Asia, 13(2), 1-8. DOI: $10.13005 / \mathrm{bbra} / 2076$

Ustabasi, G.S. \& Baysal, A. (2019). Occurrence and risk assessment of microplastics from various toothpaste. Environmental Monitoring and Assessment, 191(7), 438.

Wardrop, P., Shimeta, J., Nugegoda, D., Morrison, P.D., Miranda, A., Tang, M. \& Clarke, B.O. (2016). Chemical pollutants sorbed to ingested microbeads from personal care products accumulate in fish. Environmental Science \& Technology, 50(7), 4037-4044. DOI: 10.1021/acs.est.5b06280

Wells, P.G. (1984). The toxicity of oil spill dispersants to marine organisms: Acurrent perspective. In: Allen, T.E. (Ed.), Oil Spill Chemical Dispersants: Research, Experience, and Recommendations, STP 840 (American Society for Testing and Materials, Philadelphia, PA).

WPCIMSA (2009). Water Pollution Control Instruction Methods of Sampling and Analysis, No:27372Government Gazette of Republic of Turkey. 